Journal of Health Policy and Management (2018), 3(1): 34-40

https://doi.org/10.26911/thejhpm.2018.03.01.05

\title{
Factors Affecting the Quality of Microscopic Tuberculosis Examination in Madiun, East Java: A Multilevel Analysis
}

\author{
Sri Hartini'), Endang Sutisna'), Bhisma Murti1) \\ 1)Masters Program in Public Health, Universitas Sebelas Maret \\ 2)Faculty of Medicine, Universitas Sebelas Maret
}

\begin{abstract}
Background: Tuberculosis (TB) remains major cause of morbidity and mortality due to any one of infectious agent worldwide. In low income countries, Ziehl-Neelsen sputum smear microscopy is the only cost-effective tool for diagnosis and monitoring of patients on treatment. Refresher training for laboratory professionals involved in Acid Fast Bacilli (AFB) microscopy at peripheral health facilities is important. This study aimed to assess factors affecting the quality of microscopic tuberculosis examination in Madiun, East Java, using a multilevel analysis model.

Subjects and Method: A cross-sectional study conducted at 23 puskesmas (community health centers) in Madiun, East Java, from March to April 2018. A sample of 230 preparations was selected by simple random sampling. The dependent variable was quality of microscopic TB examination. The independent variables were tenure, refresher training, and accreditation status of puskesmas. The data were collected by questionnaire and analyzed by a multilevel logistic regression.

Results: Quality of microscopic TB examination was positively associated with tenure $\geq 3$ years $(b=2.77 ; 95 \% \mathrm{CI}=0.81$ to $4.73 ; \mathrm{p}=0.006)$ and accredited community health center $(\mathrm{b}=3.06 ; 95 \%$ $\mathrm{CI}=0.81$ to $4.62 ; \mathrm{p}<0.001)$. The association between refresher training and quality of microscopic TB examination was not statistically significant $(b=-0.51 ; 95 \% \mathrm{CI}=-2.33$ to $1.32 ; \mathrm{p}=0.580)$. Puskesmas had a contextual effect on quality of microscopic TB examination with ICC $=\mathbf{2 2 . 0 1 \%}$.

Conclusion: Quality of microscopic TB examination is positively associated with tenure and accredited puskesmas. Refresher training for laboratory technicians was not effective in improving the quality of microscopic TB examination Puskesmas has a considerable contextual effect on quality of microscopic TB examination.
\end{abstract}

Keywords: microscopic TB examination, quality, tenure, community health center, accreditation, multilevel analysis

\section{Correspondence:}

Sri Hartini, Masters Program in Public Health, Universitas Sebelas Maret, Jl. Ir. Sutami 36 A, Surakarta 57126, Central Java. Email: hartinis191@gmail.com

\section{BACKGROUND}

Tuberculosis (TB) is still a global health problem because in 2015 it was one of 10 infectious diseases that cause deaths above the rank of Human Immunodeficiency Virus-Acquired Immunodeficiency Syndrome (WHO, 2016). TB in Indonesia is still a public health issue that poses a global challenge that is among the countries with the highest TB burden in the world. Indonesia faces new challenges of Tuberculosis-Multi-Drug Resistant Tuberculosis
(TB-HIV), Tuberculosis and vulnerable communities that need attention (Ministry of Health, 2015a).

TB disease is an infectious disease that is transmitted through splash infectious material (airborne infection). The germ cause is Mycobacterium tuberculosis found by dr. Robert Koch announced on March 22, 1882. With a very small size, the germ cannot be seen directly by the eye and can only be seen under a microscope, so the required laboratory service facilities was 
according to the standard for the diagnosis of TB disease that can be enforced correctly (Ministry of Health, 2015a).

The estimated new TB cases by 2015 are 10.5 million and the estimated deaths due to TB is 1.4 million coupled with TB deaths with positive hiv of 0.4 million. According to the WHO report in 2015, the number of $\mathrm{TB}$ cases in Indonesia is estimated to be 1 million new TB cases per year (399 per 100,000 population) with 100,000 deaths per year (41 per 100,000 population). An estimated 63,000 cases of TB are HIV positive (25 per 100,000 population). Case Notification Rate (CNR) of all cases, reported for about 129 per 100,000 population. The total number of cases 324,539 cases, including 314,965 which are new cases. Nationally, the estimated HIV prevalence among TB patients is estimated at $6.2 \%$. The number of Tuberculosis-resistant Drugs cases is estimated to be 6700 cases from $1.9 \%$ cases from new TB cases and $12 \%$ from $\mathrm{TB}$ with re-treatment (Ministry of Health, 2017).

Early detection and good and fast treatment will cure the patient and stop the transmission. Unfortunately, early detection of this disease is still a lot of obstacles such as there is no quality laboratory to make the right diagnosis (Dabaro, 2017).

Since 1995, TB prevention program in Indonesia has been implemented by applying DOTS (Directly Observed Treatment Short-course) strategy which includes five key components which is diagnosed with bacteriological confirmation through microscopic, culture or molecular examination. Standart diagnosis in this program is a microscopic examination of TB (Sakundarno et al, 2009). In the DOTS strategy, the quality of laboratory services are as the backbone of the control program because there is no complete diagnosis without laboratory confirmation. The laboratory was used to determine whether the patient was cured or failed in treatment (Ibrahim et al, 2014). Whereas in TB eradication strategy to find and treat TB patients enter on the first pillar (WHO, 2015). The DOTS strategy is excellent for being used in countries with limited resources to address TB issues. By using a direct microscopic examination, the quality inspection will be very effective and efficient in handling the problem of TB (Shiferaw et al, 2015).

In order for $\mathrm{TB}$ control targets in Indonesia to be achieved in accordance with the set, eight national Action Plans are set up, one of them is the strengthening of TB laboratories that are described as network strengthening (Ministry of Health, 2014). Therefore, the quality consolidation and development of TB laboratory are good for the examination microscopic culture or sensitivity test. The capabilities of the TB laboratories at different levels, ranging from the simplest examination of direct microscopic examination to the sophisticated examination. Therefore, TB laboratory reference function in TB Control Program (P2TB) is very important. In order for referrals to work properly, there must be a well-functioning laboratory network (Ministry of Health, 2013).

Until now, the burden of TB cases in Madiun Regency has not been in accordance with the target set. While for TB laboratorium performance based on Quarter 2 of 2017 report, there are four Puskesmas (Community Health Centers) that have poor performance. This means that of 18 Puskesmas that took the cross test in the second quarter of 2017 , only $78 \%$ Puskesmas that have good performance while the target set at $80 \%$. From these data, it can be seen that the accuracy of microscopic examination or microscopic reading quality is still lacking. In addition, the quality of stocks in Madiun Regency also does not 
Journal of Health Policy and Management (2018), 3(1): 34-40

https://doi.org/10.26911/thejhpm.2018.03.01.05

meet the standard that is about $64 \%$ of good quality preparations while the target is $80 \%$, It indicates that the quality of laboratory microscopic examination TB in Madiun Regency still needs to be improved so that the quality of tuberculosis program increased.

\section{SUBJECTS AND METHOD \\ 1. Study Design \\ The research design used was observational analytic with cross sectional approach. The study was conducted at the Puskesmas of Madiun District from March to April 2018.}

\section{Population and Samples}

The general population in this study was microscopic Tuberculosis examination in Puskesmas throughout Madiun District while the target population was microscopic slide TB in every Puskesmas in Madiun Regency. The sample size in this study consisted of 230 microscopic Tuberculosis examination coming from 10 subjects in each unit of level 2 of 23 Puskesmas. The samples were selected through stratified random sampling technique at Puskesmas level and simple random sampling at the individual level.

\section{Study Variables}

The dependent variable was the quality of microscopic preparation of TB. The independent variables were work period, training, and accreditation of Puskesmas.

\section{Operational Definition of Variables}

The quality of microscopic Tuberculosis examination was defined as the preparation of microscopic preparations according to the spider web including specimens, staining, cleanliness, thickness, size, flatness. The measurement scale was continuous.

Puskesmas accreditation was defined as the acknowledgment of external parties (in this case the Accreditation Commission and / or Representative health ministry) to the Puskesmas regarding the system of service delivery and the quality management of the puskesmas in accordance with the established standard. The measurement scale was categorical.

Training was defined as a microscopic $\mathrm{TB}$ training that has been attended by laboratory personnel based on the certificate owned. The measurement scale was categorical.

Working period was defined as the time that laboratory personnel have achieved since performing the first microscopic examination tasks up to the time of the study. The measurement scale was continuous.

\section{Data Analysis}

The univariate analysis was conducted to see the frequency distribution (n) and percent (\%) characteristics of research subjects. Bivariate analysis was done to study the correlation between TB microscopic preparation quality and independent variable using chi-square test and odds ratio (OR) with $95 \%$ confidence interval (CI). The multivariate analysis was done using logistic regression through multilevel approach.

\section{Research Ethics}

The research ethics included informed consent, anonymity, confidentiality and ethical clearance. The ethical clearance in this study was conducted in Dr. Moewardi hospital, Surakarta, Central Java.

\begin{tabular}{l}
\hline RESULTS \\
\hline 1. Univariate Analysis \\
Table 1 shows that the subjects of poor \\
quality dosage study were $104(45.2 \%)$, and \\
the good stock quality was 126 respondents \\
$(54.8 \%)$. Respondents who have a working \\
period of <3 years are 140 (6o.9\%), and \\
who have a working period of $\geq 3$ years were \\
about 90 (56.5\%). Study subject who have \\
not been training were $150(65.2 \%)$, and \\
those who had training were $80(35.8 \%)$.
\end{tabular}


Accredited puskesmas were for about 180 (78.3\%), and unaccredited puskesmas were

Table 1. Univariate Analysis

\begin{tabular}{lcc}
\hline \multicolumn{1}{c}{ Variable } & Frequency & (\%) \\
\hline Quality of microscopic & & \\
Tuberculosis examination & 104 & 45.2 \\
Poor & 126 & 54.8 \\
Good & & \\
Tenure & 140 & 60.9 \\
$<3$ years & 90 & 39.1 \\
$\geq 3$ years & & 65.2 \\
Training & 150 & 35.8 \\
No & 80 & 78.3 \\
Yes & & 21.7 \\
Accreditation & 180 & \\
Yes & 50 & \\
No & & \\
\hline
\end{tabular}

50 community health centers $(21.7 \%)$.

Table 2. Bivariate analysis of the quality of microscopic Tuberculosis examination determinants

\begin{tabular}{|c|c|c|c|c|c|c|c|c|c|}
\hline \multirow{2}{*}{$\begin{array}{c}\text { Independent } \\
\text { Variable }\end{array}$} & \multicolumn{2}{|c|}{$\begin{array}{c}\text { Poor } \\
\text { Preparation }\end{array}$} & \multicolumn{2}{|c|}{$\begin{array}{c}\text { Good } \\
\text { Preparation }\end{array}$} & \multicolumn{2}{|c|}{ Total } & \multirow[t]{2}{*}{ OR } & \multirow[t]{2}{*}{ 95\% CI } & \multirow[t]{2}{*}{$\mathbf{p}$} \\
\hline & $\mathbf{n}$ & $\%$ & $\mathbf{n}$ & $\%$ & $\mathbf{n}=\mathbf{2 3 0}$ & \% & & & \\
\hline Tenure & & & & & & & & 2.24 to & $<0.001$ \\
\hline$<3$ years & 81 & 77.8 & 23 & 22.2 & 104 & 100 & 3.99 & 7.15 & \\
\hline$\geq 3$ years & 59 & 46.8 & 67 & 53.2 & 126 & 100 & & & \\
\hline Training & & & & & & & & 1.63 to 5.2 & $<0.001$ \\
\hline No & 81 & 62.1 & 69 & 37.9 & 150 & 100 & 2.91 & & \\
\hline Yes & 23 & 23 & 57 & 77 & 80 & 100 & & & \\
\hline Accreditation & & & & & & & & 2.67 to & $<0.001$ \\
\hline Yes & 96 & 79.3 & 84 & 20.7 & 180 & 100 & 6.00 & 13.49 & \\
\hline No & 8 & 9.7 & 42 & 90.3 & 50 & 100 & & & \\
\hline
\end{tabular}

Table 3. The results of multilevel logistic regression on the determinants of quality of microscopic Tuberculosis examination

\begin{tabular}{lcccc}
\multicolumn{1}{c}{ Variable } & Coefficient & \multicolumn{2}{c}{$\mathbf{9 5 \%}$ CI } & \multirow{2}{*}{ p } \\
\cline { 3 - 4 } & (b) & Lower Limit & Upper Limit n & \\
Fixed Effect & 2.77 & 0.81 & & \\
Tenure & -0.51 & -0.51 & 4.37 & 0.006 \\
Training & 3.06 & 0.81 & -2.33 & 0.580 \\
Health Center Accreditation & & & 4.62 & $<0.001$ \\
Random Effect & 9.28 & 0.28 & & \\
Health Center & & & & \\
Var (Constants) & & & & \\
ICC= 22.01\% & & & & \\
Likelihood Ratio Test $\mathrm{p}=-120.9$ & & & & \\
\hline
\end{tabular}

2. Bivariate analysis on the quality of miscroscopic TB examination

Bivariate analysis showed the relationship of independent variables (tenure, training, and accreditation) with dependent variable (quality of microscopic TB preparation).
The complete result of bivariate analysis can be seen in table 2 .

3. Multilevel Analysis on the quality of miscroscopic TB examination

On table 3, the result of ICC was $22.01 \%$. This indicator showed that the health 
Journal of Health Policy and Management (2018), 3(1): 34-40

https://doi.org/10.26911/thejhpm.2018.03.01.05

center in each strata have a contextual effect on the variation of microscopic TB preparation quality by $22.01 \%$. This number was greater than the standard of role of thumb size by $8-10 \%$, then the contextual effect of the health center which shown from multilevel analysis was very important to be noted.

There was an effect of tenure on the quality of microscopic TB preparation and it was statistically significant. Respondents who have work tenure of $\geq 3$ years were more likely to have good performance than those who have work tenure of $<3$ years ( $\mathrm{b}=2.77 ; 95 \% \mathrm{CI}=0.81$ to $4.73 ; \mathrm{p}=0.006)$. Training did not have effect on the quality of microscopic TB preparation $(b=-0.51$; $95 \% \mathrm{CI}=-2.33$ to $1.32 ; \mathrm{p}=0.580$ ).

Puskesmas accreditation was associated with the quality of microscopic TB examination and it was statistically significant. Accredited puskesmas was more likely to have a better quality of TB examination than puskesmas without accreditation $(\mathrm{b}=3.06 ; 95 \% \mathrm{CI}=0.81$ to 4.62 ; $\mathrm{p}<0.001)$.

\section{DISCUSSION \\ 1. The effect of tenure on the quality of microscopic TB examination}

The result of analysis showed that there was an effect of work tenure on the quality of microscopic TB preparation and it was statistically significant. Tenure $\geq 3$ years were more likely to have a better quality of TB microscopic preparation than those who have $<3$ years of work tenure.

The result of this study was in line with a study by Dan et al. (2015), which showed a positive relationship between work tenure and the performance quality of health personnel at health center in South Minahasa District. A study by Kustiyati et al (2017), stated that work tenure affected the performance of health personnel on deli- very planning and prevention of complications program in Sukoharjo District.

A theory stated by Robin (2003) stated that work tenure showed a positive relationship with someone's work productivity. Work tenure was a good rationale for employee's productivity. A person who has been working for a long time has a broader perspective and experience that would form workers' behavior.

2. The effect of on the quality of microscopic TB examination

The result of analysis showed that there was no effect of training on the quality of microscopic preparation and it was statistically insignificant.

Mizawati et al. (2016), which stated that health personnels who conduct training have a higher quality of performance than midwives who never got the training with 2 points difference (95\% $\mathrm{CI}=1,71-2,51)$ the study was conducted on the quality of health personnel performance in early detection of malaria during pregnancy in Central Bengkulu District.

A study by Aldusary et al. (2018) also stated that there was a significant effect between training and performance. The study used an experimental method where there was a group of health personnel in pre-training Cardio-pulmonary Resusitation (CPR) and post-training (CPR). Pretraining groups showed lower results than the post-training group. This research was different because at the time of the study, the health personnel has just got training about preparation so that it affected the result of this study.

\section{The effect of puskesmas accredita- tion on the quality of microscopic TB examination}

The result of analysis showed that there was an effect of health center accreditation on the quality of microscopic TB preparation and it was statistically significant. This 
study was in line with a study by Chuang et al. (2013), which stated that there was an effect of accreditation on the performance quality of health personnel. A study by McLees et al. (2014), also mentioned that accreditation affected the quality of health personnel's performance. Accreditation was an acknowledgment given by an indepedent organization of accreditation which established by the Minister after fulfilling the Accreditation standard (Ministry of Health Regulation, 2015) aimed at improving the quality of patients' service and safety; improving the protection of human resources health, society, environment, and the health centers, and improving the performance of health center in individual health services and/or public health.

\section{REFERENCE}

Chuang S, Howley PP, Hancock S (2013).

Using clinical indicators to facilitate quality improvement via the accreditation process: An adaptive study into the control relationship. International Journal for Quality in Health Care, 25(3): 277-283. doi: 10.1093/intqhc/mzto23.

Dabaro D (2017). Factors affecting tuberculosis case detection in Kersa District, South West Ethiopia. Journal of Clinical Tuberculosis and Other Mycobacterial Diseases. Elsevier, 9(1): 1-4. doi: 10.1016/j.jctube.2017.08.003.

Dan M, et al. (2015). Pendahuluan Pembangunan Kesehatan sebagaimana yang disebutkan dalam Undangundang Kesehatan No. 36 tahun 2009, bertujuan untuk meningkatkan kesadaran, kemauan dan kemampuan hidup sehat bagi setiap orang agar dapat terwujud derajat kesehatan masyarakat.

Kustiyati S, et al. (2017). Determinan
Faktor Yang Berhubungan Dengan Kinerja Bidan Dalam Program Perencanaan Persalinan Dan Pencegahan Komplikasi (P4K). Gaster, XV(1). Available at: http://jurnal.stikes-aisyiyah.ac.id/index.php/gaster/article/viewFile/131/123.

McLees AW, et al. (2014). Advances in public health accreditation readiness and quality improvement: evaluation findings from the National Public Health Improvement Initiative. Journal of public health management and practice: JPHMP, 20(1): 29-35. doi: 10.1097/PHH.ob013e31829ff726.

Mizawati A, Hakimi M, Kusnanto H (2016). Kinerja bidan desa dalam deteksi dini kasus malaria. 31-40.

Sakundarno et al. (2009). Insufficient quality of sputum submitted for tuberculosis diagnosis and associated factors, in Klaten district, Indonesia. BMC Pulmonary Medicine, 9: 1-11. doi: 10.1186/1471-2466-9-16

Shiferaw MB, et al. (2015) "Tuberculosis laboratory diagnosis quality assurance among public health facilities in West Amhara Region, Ethiopia. PLoS ONE, 10(9): 10-18. doi: 10.1371/journal.pone.0138488

Aldosary FF (2018). The use of high-fidelity mannequin trainig to improve the quality of healthcare providers' performance of CP. 4(2): 1-5. doi: 10.15761/JTS.1000213.

Kemenkes RI (2013). Pedoman Jejaring Dan Pemantapan Mutu Pemeriksaan Mikroskopis Tuberkulosis. Jakarta

(2015). Pedoman Jejaring dan Pemantapan Mutu Laboratorium Tuberkulosis. Jakarta (2017). Modul Pelatihan Laboratorium Tuberkulosis Bagi Petugas di Fasyankes. Jakarta

Permenkes No 46 tahun 2015 tentang 
Journal of Health Policy and Management (2018), 3(1): 34-40

https://doi.org/10.26911/thejhpm.2018.03.01.05

Akreditasi Puskesmas, Klinik Pratama, Tempat Praktik Mandiri Dokter, Dan Tempat Praktik Mandiri Dokter Gigi: Kemenkes RI.
Permenkes RI (2016). Penanggulangan Tuberkulosis. Kementerian Kesehatan World Health Organization (2016). Global Tuberculosis Report. 